\title{
Assessing the economic security of industrial enterprises: analysis of the environmental component
}

\author{
Elena Karanina, and Nataliya Maksimova* \\ Vyatka State University, Moskovskaya str., 36, 610000 Kirov, Russia
}

\begin{abstract}
The article clarifies the concept of economic security of an industrial enterprise, analyzes the indicators of environmental safety developed by modern researchers. The authors of the article highlight the environmental indicators of the economic safety of industrial enterprises, build a correlation-regression trend model of the coefficient of products' environmental friendliness.
\end{abstract}

\section{Introduction}

Nowadays the solution of environmental problems is a priority direction of Russia, which is evidenced by the Fundamentals of State Policy in the Field of Environmental Development of Russia for the period up to 2030. Scientific and technological progress has a positive impact on the economy of the Russian Federation and the world. However, there is also a downside to this situation. Development of the industrial sector leads to the increase of the anthropogenic load on the environment, depleting natural resources. The larger the city, the higher the level of pollution in it. Thus, the environmental component comes to the fore when determining the level of economic security, both for the organization and for the country. In the context of globalization of public life, some environmental problems go beyond national boundaries and become interethnic. At the international level, ways of achieving environmental safety are also worked out. The main goal here is the prevention of economic and environmental accidents, and the rational use of natural resources.

An important factor in ensuring environmental safety at the enterprise is Russia's accession to the World Trade Organization (WTO), which requires products and all production processes to comply with international environmental standards.

One of the priority tasks of the Russian economic development is developing a strategy aimed at invariably positive dynamics of indicators, adoption of optimal managerial economic and environmental decisions. The environmental component of economic security today is the most important category that affects the stability of the socio-economic system in general [10]. Environmental indicators of economic security in this industry is relevant at the international, national, regional levels, and also at the level of the industry and even the organization. To implement this task at the level of the industrial sector, scientific studies of accounting for environmental factors, indicators in the activities of

*Corresponding author: info-mna@yandex.ru 
enterprises are important as they allow to monitor and make a forecast taking into account relevant risks and determining ways to solve the problem.

Currently, there are several areas of study of economic and environmental problems: at the national, regional levels and at the level of the organization.

Many researchers study this problem at the national level: Makhutov N., Gadenin M., Kharchenko S., Dorokhina E., Kopytina M., Kitaev D., Shchukina T., Apoikova E., Brons F.A., Carvalho M.M.D., Zankul E.D.S., Nadtochiy Yu.V., Goncharova A.R., Ivanatova N.P., Stoyanova I.A., Kravchenko N.A., Agafonov V.B., Ignatiev D.A. etc.

Economists dealing with issues of economic and environmental security at the regional level are: Khovansky A., Bogachev I., Bayan E., Karanina E.V., Ilysheva N., Baldesku E., Vershinina N.A., Hasanov R., Korableva A., Smirnova L.N., Ivanov O.P., Zyryanov S.G. etc.

Researchers studying this issue within the framework of the organization (enterprise) are: Kazakova N.A., Kogdenko V.G., Chuikin S., Kolosov A., Khovanskiy A., Bayan E., Bogachev I., Tauras P., Videira N ., Tays V.N., Lewis C.F.M., Otavio J. de O., Zakharyan S., Gedganov E., Yun A., Matsneva E.A., Magaril E.R. etc.

The purpose of this study is to develop the most optimal indicators which are convenient to use in practical conditions of the environmental component of the economic security at an industrial enterprise.

To do this, it is necessary to solve the following tasks:

- to clarify the concept of environmental safety of an industrial enterprise;

- to analyze various indicators of environmental safety, formulated by modern researchers;

- to develop an economic model for determining environmental safety and the vector of its development on the example of light industry enterprises.

On the basis of the analysis, the article aims to identify indicators of environmental safety and present formulas that allow the most accessible and convenient way to assess the environmental safety of the industrial enterprises, and to build a correlation-regression model of the trend of the indicator of environmental safety. It will help to simplify the system for determining the environmental safety of the enterprise and optimize the process of a comprehensive assessment of its economic security.

\section{Materials and methods}

While analyzing the scientific literature, the authors have used the deconstruction method: the article has fragments of research by other authors that correspond to the topic. The assessment of the text was carried out, the interpretation of other authors' thoughts was presented with reference to the original source. The axiomatic method was used to substantiate the concept of "environmental safety of an industrial enterprise". On the basis of previously proposed definitions, the authors have formulated a clear concept. The method of apperting was also used: the author's thoughts regarding the clarification of the concept were related to the results of other researchers. The descriptive method was used to identify the indicators of the environmental safety of the enterprise, the proposals of other researchers were studied, the key points were highlighted. On this basis some own indicators were identified and an economic model was built. Correlation-regression analysis was used in the construction of this model. The decision on the allocation of calculated indicators was made taking into account an expert survey of leading specialists of light industry enterprises.. 


\section{Results and discussion}

\subsection{Definition of "environmental safety of an enterprise"}

One of the characteristic features of the modern world is the consumer attitude and extensive use of natural resources. The current situation can be considered as conditions of environmental hazard. The concept of "environmental hazard" can be characterized as the opposite of the definition of "environmental safety".

Article 1 of the Federal Law "On Environmental Protection" defines environmental safety as a state when the natural environment and vital human interests are protected from the potentially negative impact of any activity and various emergencies.

Ivantsova E.A. and Kuzmin V.A. define "ecological and economic security" as a complex of various social, economic and environmental conditions that contribute to the sustainable development of society, an increase in the standard of living, an improvement in the state of the environment [6].

According to Ilyakova I.E., "environmental safety of an enterprise" is a situation opposite to environmental hazard, when there are no threats and risks to others, results of the enterprise's activities exclude danger to human life and health, corresponding to the needs of society or business [7].

Agafonov V.B. and Ignatiev D.A. believe that ensuring environmental safety is directly related to compliance with the requirements and rules of the legislation of the Russian Federation in the field of environmental protection and environmental standards [1].

In a global sense, Kravchenko N.A. interprets the concept of environmental safety as a guarantee of preventing environmental accidents and disasters, the level of compliance of existing conditions with the requirements of preserving the health of the population and ensuring socio-economic development [12].

Nadtochy Yu.V. gives the following definition to the concept of "environmental safety": this is a state of absence of danger for humanity and the environment [16].

Having analyzed these concepts and projected them to the enterprise level, we formulate the following definition. "Environmental safety of an industrial enterprise" is a steady state of an enterprise characterized by using environmental assessment and monitoring in management activities, ensuring the production of products in compliance with the requirements of mandatory and voluntary certification, ensuring the production process without violating legislation on environmental pollution.

\subsection{Indicators of environmental safety of the enterprise}

An environmentally friendly enterprise must meet a number of requirements, the most important are the optimal use of resources and the minimum volume of emissions of substances that pollute the environment. In the activity of any industrial enterprise, the object of management should include environmental indicators.

Let us consider the indicators of environmental safety at various levels of management.

Based on the conducted factor analysis, Hvan M.S. proposes to identify six factors that affect the environmental situation in the regions of the Russian Federation (Table 1).

Table 1. Factors affecting the environmental situation in the regions of the Russian Federation [21]

\begin{tabular}{|l|l|}
\hline \multicolumn{1}{|c|}{ Factors } & \multicolumn{1}{c|}{ Notes } \\
\hline ecological potential of the region & $\begin{array}{l}\text { replacement of used materials and raw materials by } \\
\text { organizations that are safer for the environment, } \\
\text { reduction of carbon dioxide emissions, using of } \\
\text { waste recycling, reduction of energy consumption }\end{array}$
\end{tabular}


Table 1. Continued

\begin{tabular}{|l|l|}
\hline $\begin{array}{l}\text { transport and construction development } \\
\text { potential }\end{array}$ & \\
\hline production potential & $\begin{array}{l}\text { discharge of pollutants into waste water, hazardous } \\
\text { emissions into atmospheric air, etc. }\end{array}$ \\
\hline $\begin{array}{l}\text { technogenic impact on the ecology of the } \\
\text { region }\end{array}$ & mining \\
\hline use of water resources & consumption of natural resources \\
\hline
\end{tabular}

Table 2 presents environmental factors and threats affecting economic security, according to Zimenkova E.N.

Table 2. Factors and threats to economic security [5]

\begin{tabular}{|l|l|}
\hline Factors & \multicolumn{1}{|c|}{ Threats } \\
\hline climatic conditions & risk of natural disasters and catastrophes \\
\hline resource stock & the prevailing majority of raw materials industries in the territory \\
\hline $\begin{array}{l}\text { environmental } \\
\text { pollution level }\end{array}$ & exhaustion of natural resources \\
\hline $\begin{array}{l}\text { recreational potential } \\
\text { and others }\end{array}$ & nuclear burial \\
\hline & import of waste from other countries \\
\hline & $\begin{array}{l}\text { lack of specially equipped landfills for the disposal of hazardous } \\
\text { waste }\end{array}$ \\
\hline & growth of anthropogenic and technogenic impact, etc. \\
\hline
\end{tabular}

Yachmeneva V.M. and Osmanova Z.O. distinguish external and internal factors that affect the environmental and economic safety of an industrial enterprise (Table 3).

Table 3. External and internal factors of environmental and economic security of an industrial enterprise [25]

\begin{tabular}{|l|l|}
\hline External factors & Internal factors \\
\hline regulatory framework & environmental monitoring \\
\hline scientific and technical progress & $\begin{array}{l}\text { compliance with the norms } \\
\text { and requirements of the } \\
\text { legislation }\end{array}$ \\
\hline $\begin{array}{l}\text { environmental policy of the state (including the level of state } \\
\text { support aimed to stimulate the conservation of the } \\
\text { environment) }\end{array}$ & \\
\hline social conscience of society & \\
\hline endowment with natural resources & \\
\hline natural disasters and anthropogenic impact & \\
\hline
\end{tabular}

Nikitenko $\mathrm{Yu} . \mathrm{V}$. proposes the following indicators to assess environmental safety (Table 4): 
Table 4. Environmental safety indicators [17]

\begin{tabular}{|c|c|}
\hline Indicators & Notes \\
\hline potential environmental hazard ratio & $\begin{array}{l}\text { expressed in points corresponding to the } \\
\text { class of environmental hazard of the enterprise: } \\
\text { 1st class - } 400 \text { points, } 2 \text { nd - } 100,3 \text { rd - } 36 \text {, 4th - } \\
\text { 4, 5th - } 1\end{array}$ \\
\hline $\begin{array}{l}\text { coefficient of exceeding the normative zone } \\
\text { of environmental pollution }\end{array}$ & $\begin{array}{l}\text { harmful emissions should not exceed the } \\
\text { maximum permissible concentration }\end{array}$ \\
\hline $\begin{array}{l}\text { coefficient of exceeding the standard } \\
\text { volume of discharges of harmful substances } \\
\text { into water bodies }\end{array}$ & $\begin{array}{l}\text { discharges should not exceed the } \\
\text { maximum permissible norms }\end{array}$ \\
\hline $\begin{array}{l}\text { coefficient of exceeding the standard } \\
\text { volume of emissions of harmful substances into } \\
\text { the atmosphere }\end{array}$ & similar to the previous coefficient \\
\hline $\begin{array}{l}\text { population factor of the zone of harmful } \\
\text { environmental impact }\end{array}$ & $\begin{array}{l}\text { determines the potential danger of the } \\
\text { enterprise for the population }\end{array}$ \\
\hline $\begin{array}{l}\text { greening factor of the environmental impact } \\
\text { zone }\end{array}$ & $\begin{array}{l}\text { the presence of vegetation in the zone of } \\
\text { environmental impact }\end{array}$ \\
\hline $\begin{array}{l}\text { enterprise environmental impact value } \\
\text { factor }\end{array}$ & $\begin{array}{l}\text { relative natural, social, cultural, historical } \\
\text { and other values of the territory. The method } \\
\text { of expert evaluation is used }\end{array}$ \\
\hline $\begin{array}{l}\text { generalized indicator of the environmental } \\
\text { hazard of an enterprise }\end{array}$ & $\begin{array}{l}\text { internal and external factors are taken into } \\
\text { account }\end{array}$ \\
\hline
\end{tabular}

According to A.A. Vetrova. environmental and economic management at the regional level is influenced by the following factors: information and communication, time factors of exposure, economic factors, social and motivational, natural, technical and technological.

Some authors [3] propose to divide all indicators into 3 blocks in order to determine the generalized index of environmental safety (Table 5).

Table 5. Indicators determining the generalized index of environmental safety [3]

\begin{tabular}{|l|l|}
\hline Set of indicators & \multicolumn{1}{|c|}{ Indicators } \\
\hline $\begin{array}{l}\text { Socio-economic } \\
\text { development set }\end{array}$ & $\begin{array}{l}\text { People visiting hospitals for 1 shift, the number of preschool } \\
\text { institutions, the number of cultural and leisure facilities, the } \\
\text { number of sports facilities, investments, the number of unprofitable } \\
\text { organizations (enterprises), the number of profitable organizations, } \\
\text { the number of law enforcement agencies by management levels, } \\
\text { etc. }\end{array}$ \\
\hline Ecological set & $\begin{array}{l}\text { The costs of environmental protection, the number of objects that } \\
\text { pollute the environment, the number of waste disposal facilities, } \\
\text { the area under crops. }\end{array}$ \\
\hline $\begin{array}{l}\text { Human development } \\
\text { set }\end{array}$ & $\begin{array}{l}\text { Fertility rate, the number of students in preschool, general } \\
\text { education and sports organizations. }\end{array}$ \\
\hline
\end{tabular}

Based on the results of a theoretical and methodological analysis of literary sources and an expert survey of leading specialists of light industry enterprises of the North-West region, we have identified the following enviromental indicators, which are simple and understandable for use and effective for implementation in the management process of industrial enterprises: the coefficient of environmental friendliness of production and the coefficient of product environmental friendliness [13].

To determine the coefficient of environmental friendliness of production, the following formula is presented:

$$
\begin{aligned}
& \mathrm{K}_{1}=\frac{\mathrm{p}-\mathrm{s}}{\mathrm{z}} \text {, where }(1) \\
& \mathrm{K}_{1} \text { - environmental factor of production, }
\end{aligned}
$$


$\mathrm{p}$ - environmental costs,

$\mathrm{s}-$ fines and other payments for violations,

$\mathrm{z}$ - total costs (suggested by authors).

To determine the coefficient of environmental friendliness of products, the following formula is presented:

$\mathrm{K}_{2}=\frac{V_{s}}{V_{o}}$, where

$\mathrm{K}_{2}$ - environmental factor of products,

$\mathrm{V}_{\mathrm{s}}$ - volume of products certified for environmental friendliness and safety,

$\mathrm{V}_{\mathrm{o}}$ - the total volume of products manufactured by the enterprise (suggested by authors).

It should be noted that in the field of environmental management, the legislation of the Russian Federation provides the statistical reporting form 4-OS "Information on the current costs of environmental protection". However, it must be surrendered only by those enterprises and individual entrepreneurs that have treatment facilities at their production and their costs for environmental measures exceed 100,000 rubles per year. None of the enterprises in question meet these criteria. In this regard, the calculation of the coefficient of environmental friendliness of production for the studied enterprises is not possible.

It is also worth emphasizing the fact that in order to get a real picture when calculating the level of environmental friendliness of production, it is necessary to deduct penalties from the volume of environmental costs. Unfortunately, this area is financially more profitable for enterprise managers to pay fines than to install and maintain treatment facilities. Thus, most of the environmental costs at industrial enterprises are reduced only to the payment of fines. Due to the fact that the analysis of enterprises is carried out on a retrospective basis, it is very difficult to apply this indicator. However, this does not diminish its importance when used by managers in real time to monitor environmental safety as a component in assessing the economic security of an enterprise.

Based on the results of the studied enterprises of light industry in the North-West region, the authors have compiled a correlation-regression model of the trend of the coefficient of environmental friendliness of products (Figure 1).

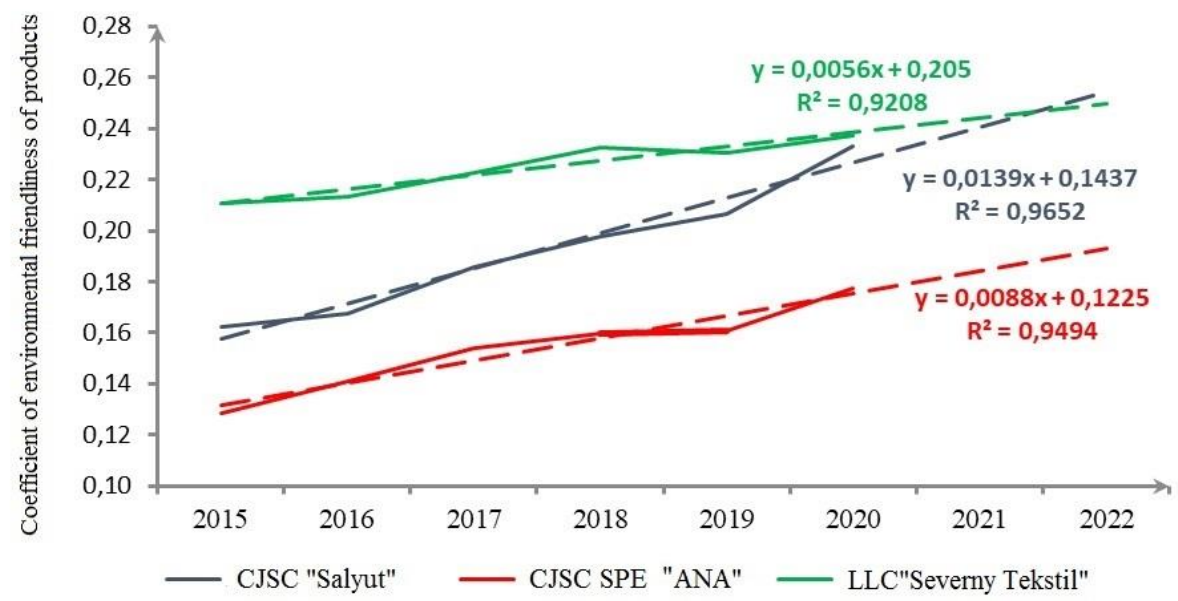

Fig. 1. Correlation-regression model of the trend of the coefficient of environmental friendliness of products.

The analysis of the graphs shown in Figure 1 shows the trend of changes in the coefficient of environmental friendliness of products at three large enterprises of light 
industry. The coefficient of determination of all enterprises is high, the nature of the dependence is linear, which confirms the significant influence of this indicator on production activities and the economic security of the enterprise. It should be noted that 5 enterprises participated in the calculations. For two of them, it was not possible to build graphs due to the fact that only the volume of products subject to mandatory certification was taken into account. Enterprises not shown in Figure 1 produce goods that are not subject to mandatory certification and do not practice voluntary certification. Currently, there is a fairly high competition in this industry and the use of voluntary certification undoubtedly increases the level of customer confidence. It also characterizes the company from a positive side. Thus, it is worth noting that enterprises not shown in Figure 1 have the potential for development.

\section{Conclusion}

Currently, the role of environmental factors and indicators in the work of industrial enterprises is increasing. One of the important conditions for the development of the environmental component is the organization and implementation of environmental control, continuous monitoring of the state of natural resources at all stages of the enterprise's life cycle. Continuous monitoring allows to make various kinds of additions in time and amendments to the environmental policy of the enterprise in order to reduce environmental damage.

It is worth noting that environmental regulation is a part of the global economy. Many international economic and other aspects are aimed to protect the environment.

Environmental safety is an important component of the economic security of an enterprise, influencing all activities of the organization.

In this research, the authors have analyzed and clarified the concept of environmental safety of an industrial enterprise. On the basis of the studied indicators of environmental safety, formulated by modern economists-researchers, the authors propose simple and convenient environmental indicators of economic security for use in practical conditions of industrial enterprises. Based on the results of this study, a correlation-regression model of the trend of the coefficient of environmental friendliness of products has been developed.

Practical calculation was made only for one of the two proposed indicators. The calculation of the second indicator is possible in the future, taking into account the introduction of small changes in the reporting policy of the enterprise.

It can be concluded that it is necessary to introduce more stringent requirements for the reports of enterprises in terms of the environmental component, which should lead to strict compliance with the norms and requirements of legislation in the field of ecology, and therefore increase the environmental and economic safety of the enterprise.

The results of the study can be applied in the development of comprehensive measures to assess the environmental and economic safety of an industrial enterprise, to make optimal management decisions not only at the local, but also at the regional level

\section{Acknowledgements}

We are very grateful to the organizers of the international scientific and practical conference "IV International Scientific and Practical Conference" Sustainable Development and Green Growth on the Innovation Management Platform " for the opportunity to present and publish a report on topical issues of assessing the economic security of industrial enterprises through the analysis of the environmental component. 
Place the figure as close as possible after the point where it is first referenced in the text. If there is a large number of figures and tables it might be necessary to place some before their text citation.

\section{References}

1. V.B. Agafonov, D.A. Ignatiev, Actual problems of Russian law, 5, 221 (2018)

2. A.A. Vetrova, Bulletin of Economics, Transport and Industry, 34, 382 (2011)

3. V.V. Glinsky, L.K. Serga, M.S. Khvan, Ideas and ideals, 1, 13 (2015)

4. S. Zakharyan, E. Gedgagov, A. Yun, Ecology and industry of Russia, 1, 26 (2018)

5. E.N. Zimenkova, Regional problems of economic transformation, 7, 53 (2017)

6. E.A. Ivantsova, V.A. Kuzmin, Ecology. Biology, 5, 136 (2014)

7. I.E. Ilyakova, Contensus, 9, 91 (2019)

8. N. Ilysheva, E. Karanina, E. Baldesku, E3S Web of Conferences (2020)

9. N.A. Kazakov, V.G. Kogdenko, Ecology and industry of Russia, 3, 60 (2021)

10. E.V. Karanina, N.A Vershinina, MFYuA Bulletin, 2, 21 (2016)

11. M. Kopytina, D. Kitaev, T. Shchukina, E. Apoikova, Ecology and industry of Russia, 4, 59 (2017)

12. N.A. Kravchenko, Scientific notes of the Crimean Federal University named after V.I. Vernadsky. Legal sciences, 1, 453 (2020)

13. N.A. Maksimova, Economics and Management: Problems, Solutions, 4, 93 (2021)

14. E.A. Mantseva, E.R. Magaril, Ecology and industry of Russia, 2, 54 (2013)

15. N. Makhutov, M. Gadenin, Ecology and industry of Russia, 3, 47 (2016)

16. Yu.V. Nadtochy, Asia-Pacific Region: Economics, Politics, Law, 1-2, 96 (2018)

17. Yu.V. Nikitenko, Modeling, optimization and information technology, 1, 9 (2014)

18. S. Kharchenko, E. Dorokhina, Ecology and industry of Russia, 3, 52 (2016)

19. S. Kharchenko, E. Dorokhina, Ecology and industry of Russia, 1, 42 (2017)

20. R.Kh. Khasanov, A.A Korableva, Economic policy, 6, 82 (2019)

21. M.S. Hwang, Novosibirsk State University of Economics Bulletin, 2, 346 (2015)

22. A. Khovansky, E. Bayan, I. Bogachev, Ecology and industry of Russia, 10, 58 (2016)

23. A. Khovanskiy, E. Bayan, I. Bogachev, Ecology and industry of Russia, 7, 52 (2017)

24. S. Chuikin, A. Kolosov, Ecology and industry of Russia, 3, 54 (2020)

25. V.M. Yachmenenva, Z.O. Osmanova, Economics of construction and environmental management, 3, 36 (2018)

26. F.A Brones, M.M.D. Carvalho, E.D.S. Zancul, Journal of Cleaner Production, (2017)

27. Thais, Vieira Nunhes, Luis, Cesar Ferreira Motta, Otavio, Jose de Oliveira, Journal of Cleaner Production (2016)

28. P. Tourais, N. Videira, https://www.researchgate.net (2016) 